\title{
NEW FIELD RELATIONS FROM THE EARLY PRECAMBRIAN OF WEST GREENLAND
}

\author{
B. F. Windley
}

The following new field relations were found this summer in the region between Ravns Stor $\phi$ and Sukkertoppen.

On western Nordland there is an anorthosite horizon with a maximum width of $6 \mathrm{~km}$ and a minimum length of $25 \mathrm{~km}$ which is the widest anorthosite so far known in West Greenland. This is a layered anorthosite grading into anorthositic norite which has been migmatised marginally by the surrounding hypersthene gneisses, but which is well preserved in its centre.

At Suversoq in inner Fiskefjord a major pyribolite horizon contains stratigraphic layers up to about $40 \mathrm{~m}$ wide of norite grading into anorthositic norite and of chromite-layered dunite. Chromitite layers are 20-30 cm wide and chromite-rich sequences reaching $2 \mathrm{~m}$ wide can be followed for several hundred metres.

The sapphirine locality near Sukkertoppen (Ramberg, 1948) was found to occur in the middle of a lens, about $200 \times 400 \mathrm{~m}$ in size, of hypersthene anorthosite grading into norite. The sapphirine-bearing rocks in the western Alangua region (S $\phi$ rensen, 1955) are associated with bronzitites interlayered with norites and chromite-rich dunites. Thus the sapphirine-bearing rocks in these areas have a similar mode of occurrence as those in the anorthosites of the Fiskenæsset region.

In the hornblende-biotite gneisses of the Alangua region there are several $100 \mathrm{~m}$ large inclusions of hypersthene gneiss demonstrating that the region has been through an early granulite facies metamorphism.

In the retrogressed amphibolite facies gneisses on the plateau east of S $\phi$ ndre Isortoq blue quartz is abundant, the colour having been inherited from the earlier hypersthene gneisses. Blue quartz is similarly found although only locally in the biotite gneisses of Qilangarssuit island and thus corroborates Berthelsen's (1955) conclusion 
that the rocks of this island have been through an early granulite facies metamorphism. In the gneisses there are many discordant amphibolite dykes often 15-20 $\mathrm{m}$ thick which are unmigmatised and only moderately folded. These dykes trend NNE towards the entrance of Ameralik Fjord and therefore can reasonably be regarded as belonging to the dyke swarm there described by McGregor (this report).

It is now clear that all regions of southern West Greenland, with the exception of those of Godthåbsfjord and Ravns Stor $\phi$, have the same three-fold chronology: layered calcic anorthosites commonly associated with norites followed by granulite facies metamorphism followed by amphibolite facies metamorphism. In the Fiskenæsset region there is an anorthosite-pyribolite-bronzitite-peridotitechromitite suite and in the Fiskefjord region a pyribolite-noritedunite-bronzitite-chromitite suite. The only significant difference between these is in the relative abundance of rock types, the latter being more mafic to ultramafic than the former with the chromitites occurring in the ultramafic members rather than in the anorthosite. Both suites are post-dated by granulite and then amphibolite facies metamorphisms with similar age determinations of $2520 \mathrm{~m} . \mathrm{y}$. and $2610 \mathrm{~m}$. y. respectively, and therefore it is a reasonable conclusion that they are chronologically equivalent. The fact that the basic dykes of Qilangarssuit island cut a diorite body containing anorthosite inclusions and post-date the granulite facies metamorphism as shown by Berthelsen (1955) gives the most reliable clue to the relationship of the Ameralik-Godthåbsfjord chronology with that of the surrounding regions. Where the early granulite facies rocks come close to the Godthåbsfjord amphibolite facies rocks, there is, as would be expected, an intervening zone of retrogressed purple and white amphibolite facies gneisses which is wide in the Qilangarssuit - Buksefjord and Fiskefjord - Ipernat dome regions and narrow, but still present, along the east and south-east coast of Nordland.

Within the conformable metavolcanic amphibolite horizon in the Ravns Stor $\phi$ area there is a belt of well-preserved greenschist facies rocks containing volcanic breccias, amygdules and sodic 
rhyolite flows. These rocks have been only moderately flattened, minor folds are rare and pegmatites and granitic veins are absent. This horizon lies between regions that have been up to granulite facies - Fiskenæsset and Dalagers Nunatakker (Dawes, this report) and yet it is most unlikely that it has been up to this grade and subsequently retrogressed. The low-metamorphic rocks have the features of normal, progressive, weakly deformed, greenschist facies rocks which means that the volcanic formation must post-date the surrounding basement gneisses. The cover-basement contact has been "parallelised" by reworking of the gneisses.

The conformable cover-basement relations are similar to those in the Godthåb area described by McGregor (this report). The main amphibolite horizon in this area extends to the north along Godthåbsfjord through Sadelфen and Bjørneøen where its relationships are similar to those in the Ravns Stor $\phi$ area. The amphibolite contains well-preserved pillows with recognisable bun-shaped tops and indented bottoms, whereas the adjacent gneisses contain double, triple and quadruple fold interference patterns.

The effect of the reworking of the basement gneisses with or without relics of later supracrustal formations has been to produce "straight belts" in which the refoliated gneisses have a uniform trend for several tens of kilometres as exemplified by the Ravns Stor $\phi$, Godthåbsfjord and Finnefjeld areas. These contrast with the unreworked, more complex basement structures which often include complex interference patterns.

Later dykes

Berthelsen and Bridgwater (1960) described a NW-trending "red dyke" in the Alangua region which is rich in calcite-filled vesicles. There is an intense swarm of at least a hundred of these dykes rarely exceeding a metre in width extending from Alangua to Hamborgerland and Manitsoq. Numerous intersections show that these are later than the "Kangamiut dykes".

Ramberg (1948) described a NNE-trending. Kangamiut dyke near Sukkertoppen which passed from dolerite along its margins to 
gabbro and garnet amphibolite in its centre. Whereas all the smaller dykes of this swarm are of unaltered, undeformed dolerite, all wide dykes have central layers of lineated gabbro or amphibolite. These are layered dykes, the amphibolite layers commonly occurring symmetrically about the centre of the dyke. In the wider dykes the apophyses and margins are of undeformed and unmetamorphosed dolerite; on each side of the dyke this passes inwards into homogeneous hypersthene gabbro, followed inwards by homogeneous hornblende gabbro, lineated hornblende gabbro often with garnet, and finally by lineated and foliated garnet amphibolite. Layers of gabbro and amphibolite may alternate in the centre of the dyke. The maximum development of layers occurs in the widest dykes. The development of the central metamorphic layers cannot be due to the direct influence of the Nagssugtoqidian orogeny to the north, but must be a more or less primary feature, reflecting a change from stable conditions at the time of initial intrusion of the magma to conditions of stress when the last central layers crystallised. This was accompanied by a considerable increase in $\mathrm{P}_{\mathrm{H}_{2}} \mathrm{O}$ which enabled hornblende to substitute for hypersthene.

The Kangamiut dykes form an intense swarm characterised by a complicated network of abundant apophyses. In a $30 \mathrm{~km}$ traverse across the swarm there are about 100 dykes with an aggregate width of just over $1 \mathrm{~km}$ representing an extension of at least $3.6 \%$.

\section{References}

Berthelsen, A. (1955) Structural studies in the Pre-Cambrian of western Greenland I. A small body of diorite, Godthaab district. Medd. Grфnland,Bd. 135, Nr. 6.

Berthelsen, A. and Bridgwater, D. (1960) On the field occurrence and petrography of some basic dykes of supposed Pre-Cambrian age from the southern Sukkertoppen district, Western Greenland. Medd. Grфnland, Bd. 123, Nr. 3.

Ramberg, H. (1948) On sapphirine-bearing rocks in the vicinity of Sukkertoppen (West Greenland). Medd. Grфnland, Bd. 142, Nr. 5 . 
Sørensen, H. (1955) On sapphirine from West Greenland. Medd. Grønland, Bd. 137, Nr。1.

FIELD EVIDENCE OF VERY OLD PRECAMBRIAN ROCKS IN THE GODTHÅB AREA, WEST GREENLAND

\section{V.R. McGregor}

The Godthåb area, situated in the old central gneiss complex of West Greenland, has yielded two of the oldest radiometric dates yet obtained from Greenland. They are both K/Ar biotite dates, one of $2710 \pm 130 \mathrm{~m} . \mathrm{y}$. on granodiorite gneiss from Godthåb (Armstrong, 1963 ), and the other of $2610 \pm 50 \mathrm{~m} . \mathrm{y}$. on gneiss collected $55 \mathrm{~km}$ to the north and on the opposite side of Godthåbsford (Larsen and M $\phi$ ller, this report). The latter gneiss shows evidence of having undergone retrograde metamorphism from granulite facies to amphibolite facies, and its date is presumed to be related to this retrogression (Windley, in press).

Mild reactivation of parts of the central complex is indicated by several younger dates, most of them about $1800 \mathrm{~m}$. y. (Larsen and M $\phi$ ller, this report). The same authors report a $\mathrm{K} / \mathrm{Ar}$ biotite date of $1820 \pm 30 \mathrm{~m}$. y. from a late pegmatite associated with the anatectic Qôrqut granite in the central part of Godthåbsfjord. This granite is probably polycyclic, but appears to have attained its present form in the core of a narrow, elongated thermal dome.

The writer's field work during the last two summers around and east of Godthåb has shown that this area has been through at least one period of plutonic activity earlier than the one which ended 